\title{
Effect of Incubation Temperature on the Production of Fungal Cellulases
}

\section{Rania Mustafa H. G., M. N. El-Reify, M. E. H. El-Geddawy and W. S. M. Ragab \\ Food Science and Technology Dept., Faculty of Agriculture, Assiut University, Egypt.}

\section{Abstract:}

This study was aimed to investigate the optimum incubation temperature for cellulases production by Aspergillus niger AUMC 8485, Aspergillus flavus AUMC 8534 and Emericella nidulans AUMC 8581.

The obtained results showed that, the optimum incubation temperature for cellulases production as measured by cup-plate clearing zone technique was $35^{\circ}$ $\mathrm{C}$ for all the studied species. The diameter of clearing zone was 22.0, 24.5, 26.0 $\mathrm{mm}$ for Aspergillus niger, Aspergillus flavus and Emericella nidulans, respectively. In case of exo-D-1,4 gluconase (FP-ase) production, the highest enzymatic activity was obtained at $35^{\circ} \mathrm{C}$ by all the studied fungal species. Meanwhile, the highest specific activity was recorded at $40^{\circ} \mathrm{C}$ for $A$. niger and at $35^{\circ}$ C for A. flavus and E. nidulans. At the same time, the optimum incubation temperature for endo- $\beta$ - D-1,4 gluconase (CMC-ase) production was recorded at $40^{\circ}$ $\mathrm{C}$ for A. niger and E. nidulans, and at $35^{\circ} \mathrm{C}$ for A. flavus. The highest CMC-ase specific activity was observed at $40^{\circ} \mathrm{C}$ for all the studied strains. The maximum amount of reducing sugars found in the culture filtrate at $35^{\circ} \mathrm{C}$ for $A$. niger, and at $40^{\circ} \mathrm{C}$ for $A$. flavus and E. nidulans. Also, the highest amount of soluble protein was recorded at $35^{\circ} \mathrm{C}$ for A. niger and at $30^{\circ} \mathrm{C}$ for A. flavus and E. nidulans.

Keywords: Cellulases, Temperature, Aspergillus niger, Aspergillus flavus, Emericella nidulans,

Received on: $1 / 4 / 2013$

Referees: Prof. Samy I. M. Elsyiad
Accepted for publication on: 10/4/2013

Prof. Bolbol R. R. Ramadan 


\section{Introduction:}

Cellulose, the most abundant polysaccharide on earth (Coughlan, 1985) is a linear, unbranched homo-polysaccharide consisting of glucose subunit joined together via $\beta$ 1-4 glycosidic linkages, being the primary structural material of plant cell wall. Individual cellulose molecules (polymer) vary widely in length and are usually arranged in bundles or fibrils (Walsh, 2002 and Saha et al, 2006).

Cellulases are a group of hydrolytic enzymes capable of hydrolyzing cellulose to smaller sugar components including glucose subunits (Jahangeer et al, 2005). Cellulase enzymes were divided into three groups according to their mechanism: (1) Exo- $\beta-1,4$ gluconase (C1) was believed to act at first on the crystalline cellulose, modifying it in such a way that subsequent enzyme can hydrolyze the product. (2) Endo- $\beta-1,4$ gluconases (CX). The random acting enzymes will hydrolyze non-crystalline cellulose, soluble cellulose derivatives, and the $\beta$ 1,4 oligomers of glucose (Rees and Maguire, 1971 and Okazaki and Moo-Young, 1978). Glucose produced from cellulosic substrate could be further used as substrate for subsequent fermentation or other processes which could yield valuable end products such as ethanol, butanol, methane, amino acid, single-cell protein, etc. (Walsh, 2002). Cellulases have been used for several years in food processing, feed preparation, waste-water treatment, detergent formulation, textile production and in other areas. Additional potential applications include the production of wine, beer and fruit juice. Nevertheless, all these uses are of rather small magnitude compared with cellulase requirements for bioconversion of lignocellulosic biomass to fuel ethanol (Philippidis, 1994).

A battery of enzymes (hydrolytic and oxidative) produced by a variety of fungi and bacteria, work in synergy to perform lignocellulose degradation (Pérez et al, 2002). Fungi can degrade cellulose, hemicellulose and lignin in decaying plants by a complex set of excreted enzymes (Gosh and Gosh, 1992). The bestknown producers of lignocellulose-degrading enzymes are strains of Trichoderma and Aspergillus species. Other relevant microorganisms include strains of Humicola, Talaromyces, Acrophialophora, Thermoascus, Bacillus and Penicillium species (Bon and Ferrara, 2007).

Incubation temperature of the fermentation medium is a critical factor has insightful influence on metabolic activities of microorganisms (Gomathi et al, 2012). Therefore, the present research was aimed to investigate the optimum incubation temperature required for cellulases production by Aspergillus niger AUMC 8485, Aspergillus flavus AUMC 8534 and Emericella nidulans AUMC 8581 . 


\section{Materials and Methods:}

\section{Fungal species:}

Three fungal species namely: Aspergillus niger AUMC 8485, Aspergillus flavus AUMC 8534 and Emericella nidulans AUMC 8581 were obtained from Assiut University Mycological Center (AUMC). The cultures were maintained at $4^{\circ} \mathrm{C}$ on potato dextrose agar (PDA) slants containing (g/l): extract from $200 \mathrm{~g}$ of potatoes, glucose, 20.0; yeast extract, 1.0; and agar, 20.0 (Ragab,1989).

\section{Mycological procedures:}

\subsection{Preparation of spores suspension:}

Slant surfaces of PDA medium were inoculated with a young culture of fungi, then incubated at $30{ }^{\circ} \mathrm{C}$ for 5 days. Spores suspension was prepared by adding ten $\mathrm{ml}$ of sterilized distilled water to each slant. The spores were scraped with inoculating loop, then a heavy spores suspension was collected in sterilized Erlenmeyer flask and adjusted to about $1 \times 10^{-6}$ spores/ml (Ragab,1989).

\subsection{Cultivation of tested fungi:}

Cultivation of tested fungi technique of Al-Mowallad (2008) was applied with some modification as follows : The liquid medium used for growth and production of cellulases was consisted of $(\mathrm{g} / \mathrm{l})$ : $\left(\mathrm{NH}_{4}\right)_{2} \mathrm{SO}_{4}, 0.5$; L-asparagine, 0.5; $\mathrm{KH}_{2} \mathrm{PO}_{4}, 1.0 ; \mathrm{KCl}, 0.5 ; \mathrm{MgSO}_{4} .7 \mathrm{H}_{2} \mathrm{O}, 0.2 ; \mathrm{CaCl}_{2}, 0.2$; yeast extract, 0.5 ; and carboxymethyl cellulose (CMC), 10 (Eggins and Pugh, 1962). The medium was adjusted to $\mathrm{pH}$ 5.4. Fifty $\mathrm{ml}$ of the medium placed in $250 \mathrm{ml}$ cotton plugged Erlenmeyer flasks and autoclaved at $121^{\circ} \mathrm{C}$ for $20 \mathrm{~min}$. After cooling at room temperature, each flask was inoculated with one $\mathrm{ml}$ of spores suspension and then incubated at different temperatures; $25,30,35,40$ and $45^{\circ} \mathrm{C}$ for 5 days. All the experiments were performed in duplicate.

After incubation period, the contents of each flask were filtered through double layer of cheese cloth to obtain clear extract containing the crude enzyme of cellulases. The crude enzyme was used for determination of exo-D-1,4 gluconase activity, endo-ß-D 1,4 gluconase activity, diameter of clearing zone, reducing sugars and soluble protein.

\section{Enzyme assay:}

\subsection{Clearing zone technique:}

For the purpose of cellulase (s) assay, the cellulase cup plate clearing zone technique of Hankin and Anagnostakis (1977) was applied with some modification as follows: $20 \mathrm{ml}$ aliquots of sterilized cellulose-agar medium containing $0.5 \%$ carboxymethyl cellulose (CMC) were poured aseptically in each sterilized Petri-dish. The medium was allowed to cool and solidify. One cup was made per each plate by a sterilized corkborer (10 mm diameter), $0.1 \mathrm{ml}$ of culture filtrate was introduced into the cup, and then, the plates were incubated for $24 \mathrm{hrs}$. at $30^{\circ}$ C. At the end of incubation period, plates were flooded with $0.1 \%$ congo red solution for $15 \mathrm{~min}$. and then destained with $1 \mathrm{M} \mathrm{NaCl}$. The hydrolysis zones were measured.

\subsection{Exo-D-1,4 gluconase (FP-ase) activity:}

Filter paper cellulase (FP-ase) activity was carried out according to Takao et al. (1985). The assay mixture in total volume of $2 \mathrm{ml}$ containing $50 \mathrm{mg}(6 \times 1$ $\mathrm{cm}$ ) Whatman No.1 filter paper as a substrate ( in a $0.1 \mathrm{M}$ acetate buffer solution $\mathrm{pH} 5$ ) and $1 \mathrm{ml}$ of enzyme filtrate. The mixture incubated at $50-55^{\circ} \mathrm{C}$ for $60 \mathrm{~min}$. 
The released reducing sugars was determined by the dinitrosalicylic acid (DNS) method described by Miller (1959). One unit of FP-ase activity is defined as the amount of enzyme that released $1 \mu$ mole of reducing sugars from the substrate per minutes under the test conditions.

\subsection{Endo- $\beta-D$ 1,4 gluconase (CMC-ase) activity:}

Carboxymethyl cellulase (CMC-ase) activity was determined according to Takao et al., (1985). The assay mixture in total volume of $2 \mathrm{ml}$ was containing 1 $\mathrm{ml}$ of $1 \% \mathrm{CMC}$ (in a $0.1 \mathrm{M}$ acetate buffer solution $\mathrm{pH}$ 5) as a substrate and $1 \mathrm{ml}$ of enzyme filtrate. The mixture was then incubated at $50-55^{\circ} \mathrm{C}$ for $10 \mathrm{~min}$. and the released reducing sugars was determined by the (DNS) method according to Miller (1959). One unit of CMC-ase activity is defined as the amount of enzyme that released $1 \mu$ mole of reducing sugars from the substrate per minutes under the test conditions.

\section{Reducing sugars determination:}

Reducing sugars contents were determined by the method described by Miller (1959) as follows: Three $\mathrm{ml}$ of DNS reagent ( $10 \mathrm{~g}$ dinitrosalicylic acid, $2 \mathrm{~g}$ phenol, 0.5 g sodium sulfite, $10 \mathrm{~g}$ sodium chloride and add water to $1 \mathrm{~L}$ ) were added to two $\mathrm{ml}$ of aliquot filtrate in a tightly capped test tube. The mixture was heated at $90^{\circ} \mathrm{C}$ in a water bath for $15 \mathrm{~min}$. to develop the red-brown color. One $\mathrm{ml}$ of $40 \%$ potassium sodium tartrate (Rochelle salt) solution was added to stabilize the color. After cooling to room temperature in a cold water bath, the absorbance recorded by spectrophotometer at 575 $\mathrm{nm}$.

\section{Soluble protein determination:}

Soluble protein contents were determined by the method described by Lowry et al. (1951) as follows: one $\mathrm{ml}$ of aliquot filtrate was pipette into a test tube, then $5 \mathrm{ml}$ of fresh reagent ( $50 \mathrm{ml}$ of $2 \% \mathrm{Na}_{2} \mathrm{CO}_{3}$ in a $0.1 \mathrm{~N} \mathrm{NaOH}$ solution $+0.5 \mathrm{ml}$ of $0.5 \% \mathrm{CuSO}_{4}$ $5 \mathrm{H}_{2} \mathrm{O}+0.5 \mathrm{ml}$ of $1 \%$ sodium potassium tartarate ) were added and left for $10 \mathrm{~min}$. at room temperature. After that $0.5 \mathrm{ml}$ of Folin reagent $(1 \mathrm{M})$ was added rapidly and mixed for $30 \mathrm{~min}$. at room temperature. The intensity of color was determined as O.D at 750 $\mathrm{nm}$. The protein content was calculated from a standard curve of bovine serum albumin solution.

\section{Results and Discussion:}

Generally, temperature affects the rate of all biological activities of microorganisms, nutrient uptake and enzyme synthesis. Therefore, an experiment was conducted to find out the effect of different incubation temperatures $\left(25,30,35,40\right.$ and $\left.45^{\circ} \mathrm{C}\right)$ on production of cellulases by Aspergillus niger AUMC 8485, Aspergillus flavus AUMC 8534 and Emericella nidulans AUMC 8581

\section{Cellulase clearing zone:}

Data presented in Table (1) and illustrated in Fig. (1) showed that all the studied fungal species exhibited their highest celluolytic activity when incubated at $35^{\circ} \mathrm{C}$. Maximum diameter of cellulase cup-plate clearing zone observed by A. niger, A. Flavus and $E$. nidulans were 22.0, 24.5 and $26.0 \mathrm{~mm}$ respectively. Lower values of clearing zone diameter were obtained when fungi were incubated at lower or higher than the optimum temperature $(35 \square \mathrm{C})$. 
Table (1): Effect of incubation temperature on the cellulytic activity of the studied fungal species.

\begin{tabular}{|c|c|c|c|c|c|}
\hline \multirow{2}{*}{ Fungal strain } & \multicolumn{5}{|c|}{ Clearing Zone Diameter } \\
& \multicolumn{5}{|c|}{} \\
\cline { 2 - 5 } & $\mathbf{2 5}^{\mathbf{}} \mathbf{C}$ & $\mathbf{3 0}^{\mathbf{}} \mathbf{C}$ & $\mathbf{3 5}^{\mathbf{}} \mathbf{C}$ & $\mathbf{4 0}^{\mathbf{}} \mathbf{C}$ & $\mathbf{4 5}^{\mathbf{}} \mathbf{C}$ \\
\hline Aspergillus niger & 19.0 & 18.0 & 22.0 & 21.0 & ND \\
\hline Aspergillus flavus & 18.0 & 19.0 & 24.5 & 24.0 & ND \\
\hline Emericella nidulans & 20.0 & 25.0 & 26.0 & 23.5 & 22.5 \\
\hline
\end{tabular}

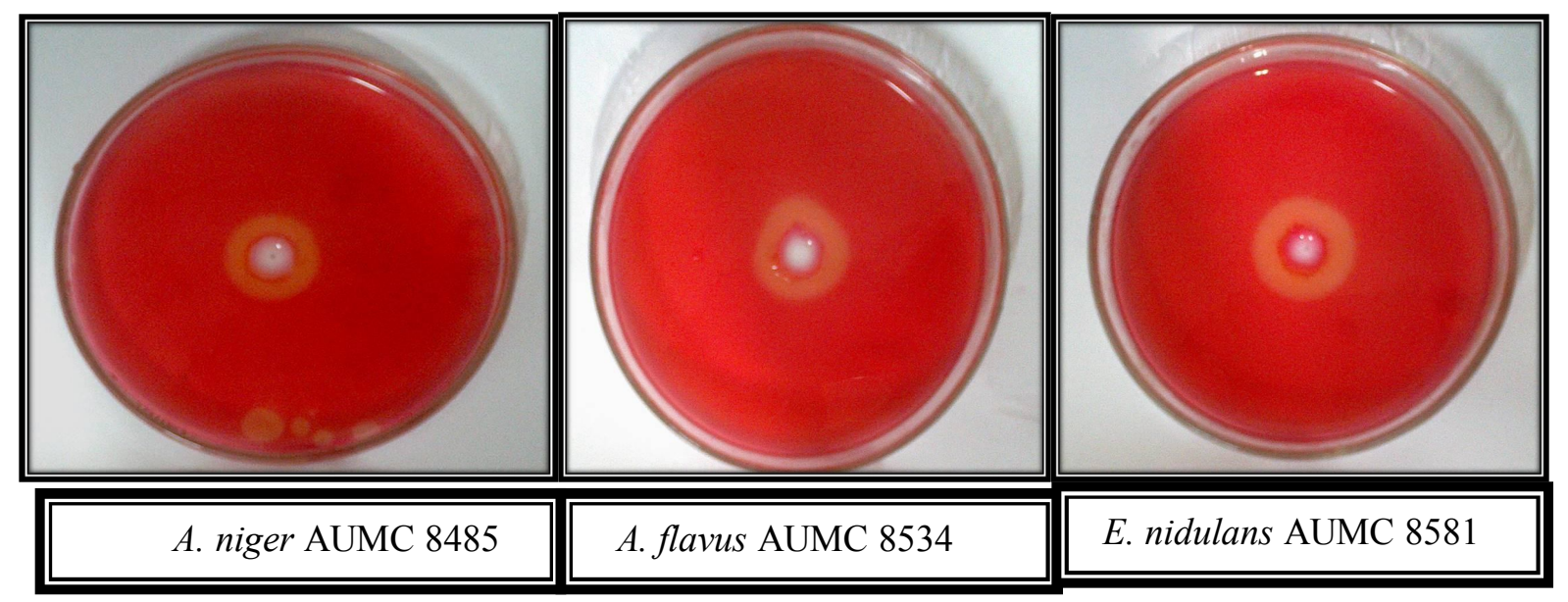

Fig. (1): Diameter of clearing zones produced by the studied fungal species at $35^{\circ} \mathrm{C}$.

\section{Exo-D-1,4 gluconase (FP-ase) activity:}

Fig. (2) showed that $35^{\circ} \mathrm{C}$ was the most optimal temperature giving maximal exo - D-1,4 gluconase activity for all tested fungal strains. It was 0.455 , 0.577 and $0.718 \mathrm{U} \backslash \mathrm{ml}$ for $A$. flavus, A. niger and E. nidulans, respectively. Production of exo - D-1,4 gluconase was increased gradually with increasing the incubation temperature from 25 to $35^{\circ} \mathrm{C}$ and then turned to the gradual decrease with increasing the incubation temperature from 35 to $45^{\circ} \mathrm{C}$. These results were agree with that obtained by Darwish (1995) and Sohail et al. (2009) who found that the optimum temperature for cellulase production by $A$. niger was $35^{\circ} \mathrm{C}$.

The specific activity of exo $-\mathrm{D}-1,4$ gluconase (FP-ase) reached to the maximum value at $35^{\circ} \mathrm{C}$ for each $A$. flavus and E. nidulans giving about 1.217 and $1.666 \mathrm{U} \backslash \mathrm{mg}$ protein, respectivally. Moreover, the optimum temperature for A. niger was $40^{\circ} \mathrm{C}$, which gave $1.203 \mathrm{U} \backslash \mathrm{mg}$ protein ( Fig. 3).

\section{Endo-ß-D 1,4 glucanase (CMC-ase) activity:}

Results obtained in Fig. (4) showed that the activity of endo-ß-D 1,4 glucanase (CMC-ase) increased as the incubation temperature increased, reaching the maximum value at $40^{\circ} \mathrm{C}$ for each $A$. niger and $A$. flavus which produced 0.756 and $0.370 \mathrm{U} \backslash \mathrm{ml}$, respectively. While it was $45^{\circ} \mathrm{C}$ for $E$. nidulans $(0.809 \mathrm{U} \backslash \mathrm{ml})$. The same trend was observed in case of endo- $\beta-D$ 1,4 glucanase (CMC-ase) specific activity which recorded the maximum value at $40^{\circ} \mathrm{C}$ for each $\mathrm{A}$. flavus and A. niger and at $45^{\circ} \mathrm{C}$ for E. nidulans ( Fig. 5). 


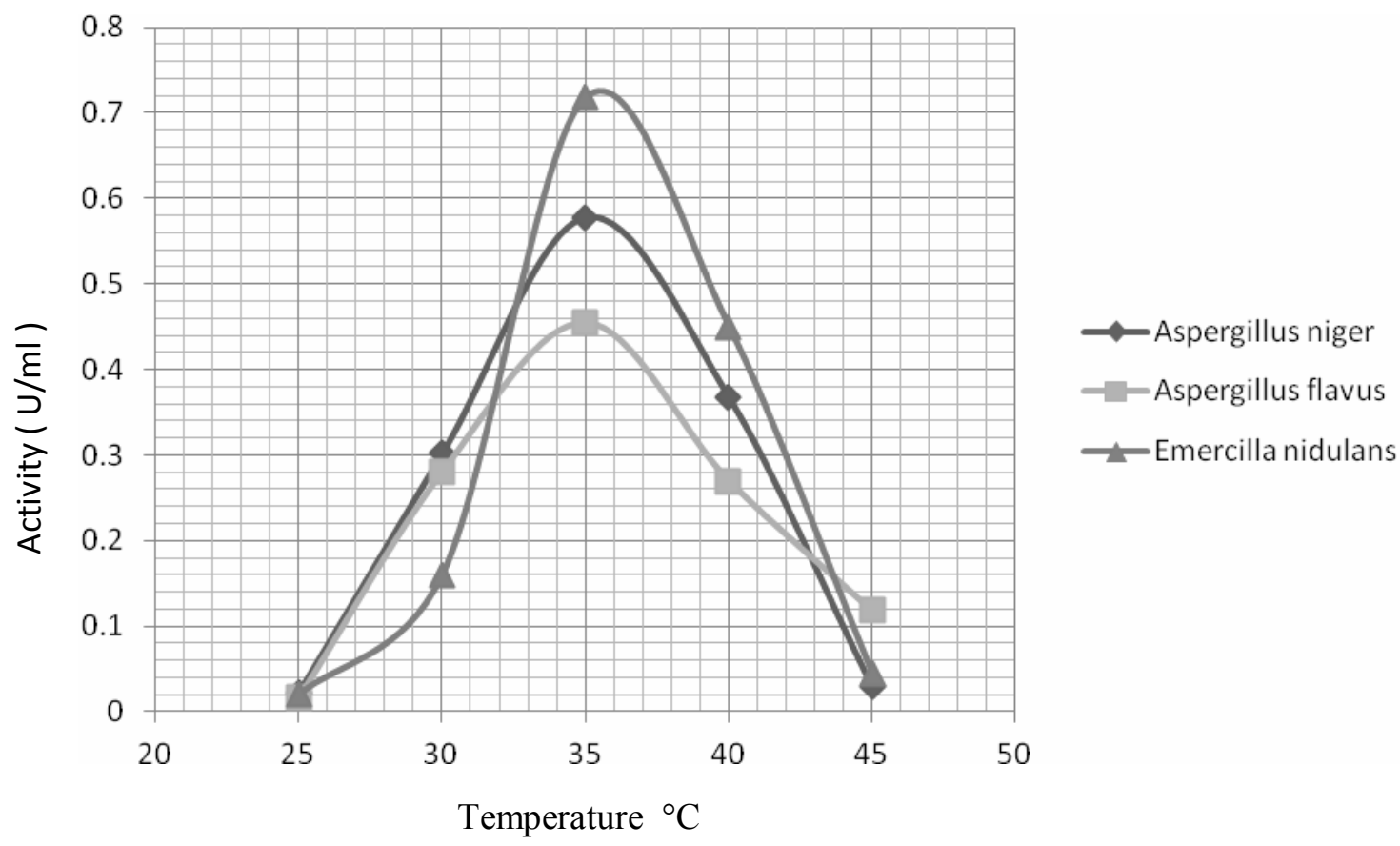

Fig. (2): Effect of incubation temperature on exo-gluconase activity by tested fungi (U\ml).

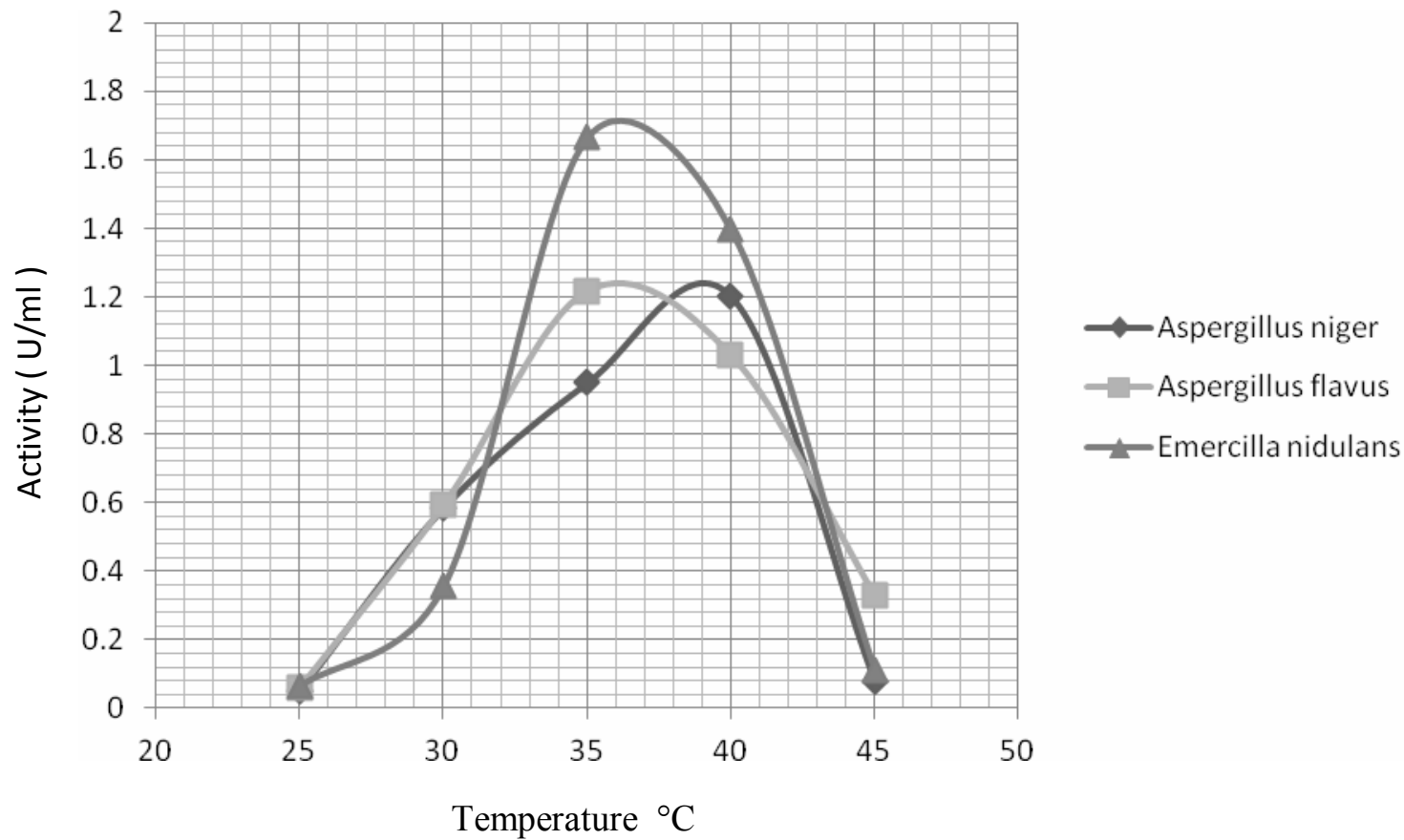

Fig.(3): Effect of incubation temperature on exo-gluconase specific activity by tested fungi (U\mg protein). 


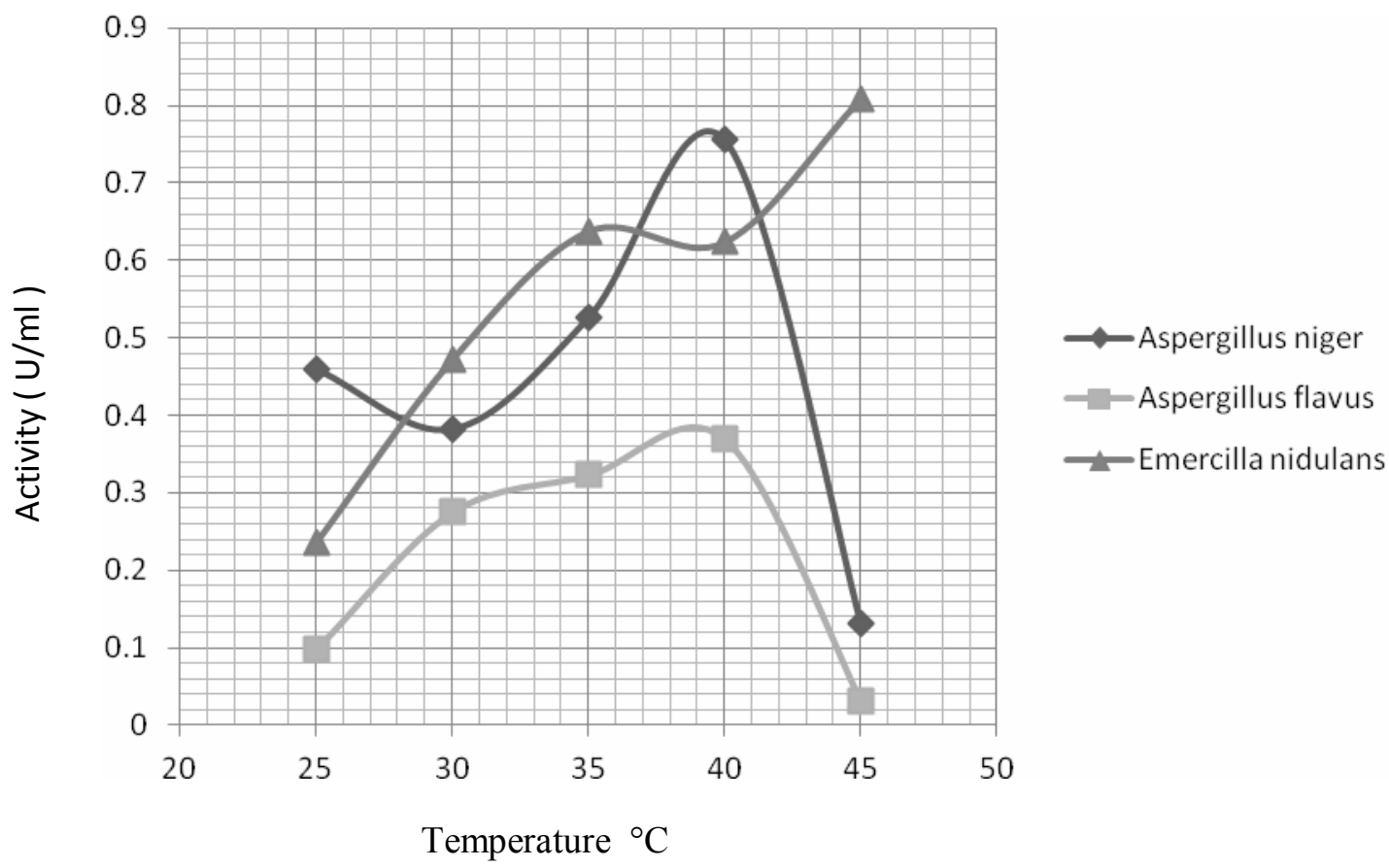

Fig. (4): Effect of incubation temperature on endo-gluconase activity by tested fungi $(\mathrm{U} \backslash \mathrm{ml})$.

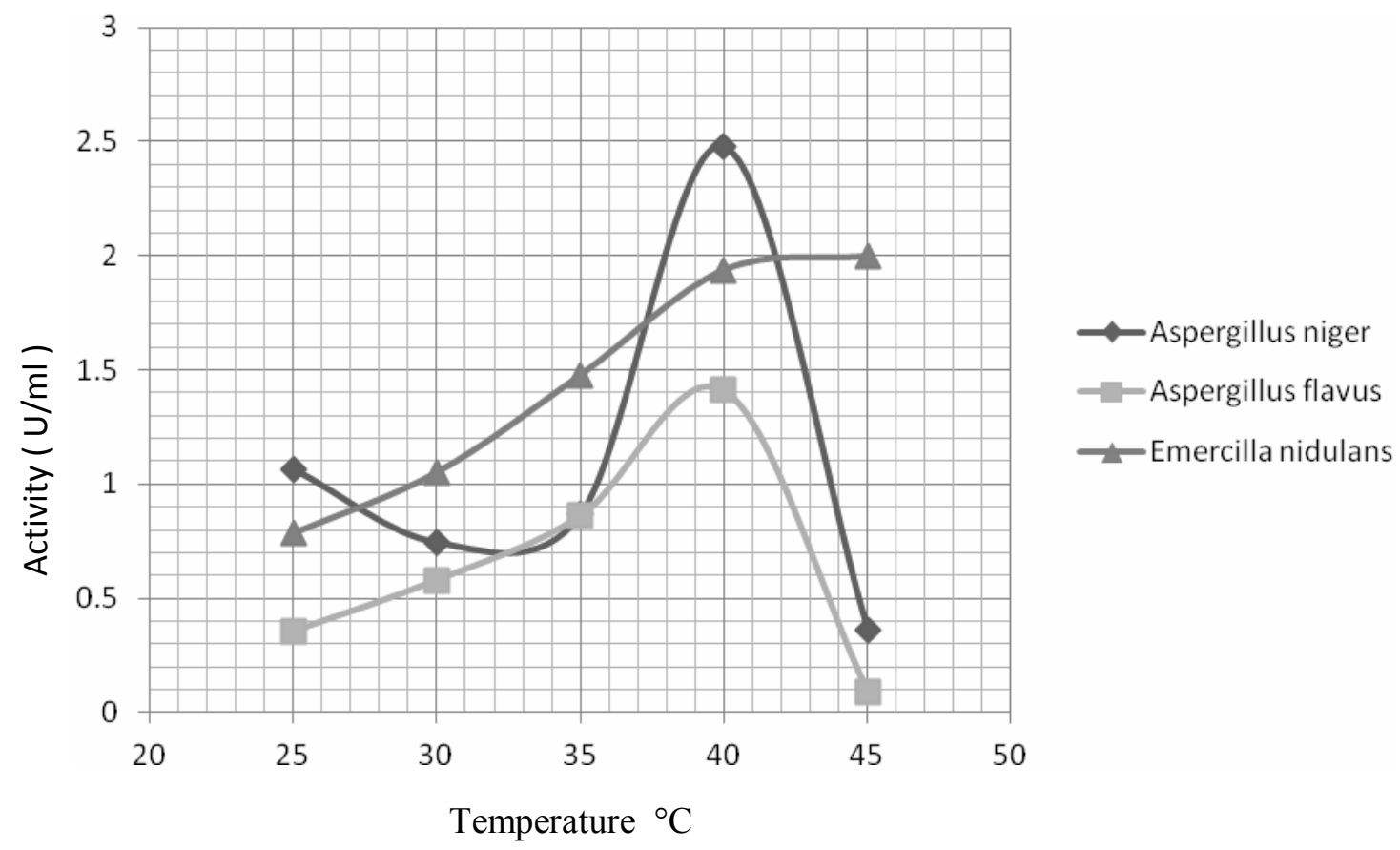

Fig. (5): Effect of incubation temperature on endo-gluconase specific activity by tested fungi (U\mg protein).

In conclusion, the optimum incubation temperature for the three fungal species recorded at $35^{\circ} \mathrm{C}$. The activity of cellulases enzymes produced by the three fungal species was varied.

\section{Reducing sugars:}


Data in Table (2) showed the amount of reducing sugars at different temperature degree $\left(25,30,35,40\right.$ and $\left.45^{\circ} \mathrm{C}\right)$. For $A$. niger: the maximum amount of reducing sugars was $220.20 \mu \mathrm{g} \backslash \mathrm{ml}$ at $35^{\circ} \mathrm{C}$, while the minimum value was 90 $\mu \mathrm{g} \backslash \mathrm{ml}$ at $25^{\circ} \mathrm{C}$. The maximum amount of reducing sugars produced from $E$. nidulans and A. flavus were 244.00 and $233.00 \mu \mathrm{g} \backslash \mathrm{ml}$ at $40^{\circ} \mathrm{C}$. Meanwhile, the minimum reducing sugars amount by $A$. flavus and E. nidulans was 27.47 and $101.00 \mu \mathrm{g} \backslash \mathrm{ml}$ at 25 and $45^{\circ} \mathrm{C}$, respectively.

\section{Soluble protein:}

The amount of soluble protein was shown in Table (3). The results illustrated that soluble protein content of A. niger was increased with the incubation temperature increasing until reached to the maximum value $(0.607 \mathrm{mg} \backslash \mathrm{ml})$ at $35^{\circ}$ $\mathrm{C}$ and turned to decrease another time. While each of A. flavus and E. nidulans had the maximum amount of soluble protein at $30^{\circ} \mathrm{C}$ it was 0.473 and 0.449 $\mathrm{mg} / \mathrm{ml}$, respectively.

Table (2): Effect of incubation temperature on the production of reducing sugars by tested fungi.

\begin{tabular}{|c|c|c|c|c|c|}
\hline \multirow{2}{*}{ Fungal strain } & \multicolumn{5}{|c|}{$\begin{array}{c}\text { Reducing sugars } \\
(\boldsymbol{\mu g} \backslash \mathbf{m I})\end{array}$} \\
\cline { 2 - 6 } & $\mathbf{2 5}^{\mathbf{}} \mathbf{C}$ & $\mathbf{3 0}^{\mathbf{}} \mathbf{C}$ & $\mathbf{3 5}^{\mathbf{}} \mathbf{C}$ & $\mathbf{4 0}^{\mathbf{}} \mathbf{C}$ & $\mathbf{4 5}^{\mathbf{}} \mathbf{C}$ \\
\hline Aspergillus niger & 90.00 & 203.07 & 220.20 & 198.67 & 218.47 \\
\hline Aspergillus flavus & 27.47 & 102.82 & 102.43 & 233.00 & 88.67 \\
\hline Emericella nidulans & 208.03 & 123.08 & 218.87 & 244.00 & 101.00 \\
\hline
\end{tabular}

Table (3): Effect of incubation temperature on the production of soluble protein by tested fungus.

\begin{tabular}{|c|c|c|c|c|c|}
\hline \multirow{2}{*}{ Fungal strain } & \multicolumn{5}{|c|}{$\begin{array}{c}\text { Soluble protein } \\
(\mathbf{m g} \backslash \mathbf{m l})\end{array}$} \\
\cline { 2 - 6 } & $\mathbf{2 5}^{\mathbf{}} \mathbf{C}$ & $\mathbf{3 0}^{\mathbf{}} \mathbf{C}$ & $\mathbf{3 5}^{\mathbf{}} \mathbf{C}$ & $\mathbf{4 0}^{\mathbf{}} \mathbf{C}$ & $\mathbf{4 5}^{\mathbf{}} \mathbf{C}$ \\
\hline Aspergillus niger & 0.432 & 0.515 & 0.607 & 0.305 & 0.365 \\
\hline Aspergillus flavus & 0.275 & 0.473 & 0.373 & 0.262 & 0.357 \\
\hline Emericella nidulans & 0.302 & 0.449 & 0.431 & 0.322 & 0.405 \\
\hline
\end{tabular}

Previous studies indicated that production of cellulases was dependent on fungal strain as well as cultivation conditions. Maximum enzyme production was recorded by A. fumigatus at $40^{\circ} \mathrm{C}$ on coir waste, and at the same time, $50^{\circ} \mathrm{C}$ was optimum for maximum cellulase production by A. niger on saw dust waste (Immanuel et al, 2007). On the other hand, Ali and Saad El-Dein (2008) obtained maximum cellulase production by $A$. niger and A. nidulans at 35 and $30^{\circ}$ $\mathrm{C}$, respectively. Also, Singh et al
(2009) defined $30^{\circ} \mathrm{C}$ as the optimum temperatures for cellulase production by $A$. heteromorphus.

\section{References:}

Ali, U.F. and Saad El-Dein H.S. (2008). Production and partial purification of cellulase complex by Aspergillus niger and $A$. nidulans grown on water hyacinth blend. Journal of Applied Sciences Research, 4(7): 875891.

Al-Mowallad, S.A.S. (2008). Studies on fungal pectinase enzymes . 
B.Sc. Thesis, Department of Food science and Technology, Faculty of Agriculture, Assiut University, Egypt.

Bon, E.P.S. and Ferrara M.A. (2007). Bioethanol production via enzymatic hydrolysis of cellulosic biomass . The Role of Agricultural Biotechnologies for Production of Bioenergy in Developing Countries, an FAO seminar held in Rome.

Darwish, Soumia M.I. (1995). Production of microbial cellulose using some agricultural wastes. M.Sc. Thesis, Food Science and Technology Department, Faculty of Agriculture, Assiut University, Egypt.

Coughlan, M. (1985). Cellulases: production, properties and applications. Biochemical Society Transactions, 13: 405-406.

Eggins, H.O.W. and Pugh, G.J.F. (1962). Iolation of cellulosedecomposing fungi from the soil. nature, 193: 94 - 95.

Gomathi, D.; Muthulakshmi, C.; Kumar, D.G.; Ravikumar, G.; Kalaiselvi, M.; and Uma, C. (2012). Submerged fermentation of wheat bran by Aspergillus flavus for production and characterization of carboxymethyl cellulase". Asian Pacific Journal of Tropical Biomedicine, S67S73.

Gosh, B.K.; Gosh, A. (1992). Degradation of cellulose by fungal cellullase. Microbial Degradation of Natural Products, ed. G. Winkelmann, VCH Publishers, Inc., New York, pp.84-126.

Hankin, L. and Anagnostakis, S.L. (1977). Solid media containing carboxymethyl cellulose to detect $\mathrm{Cx}$ cellulase activity of mi- croorganism. J. General Microbiol, 98: 109-115.

Immanuel, G.; Bhagavath C.M.A.; Raj, P.L.; Esakkiraj, P. and Palavesam A. ( 2007). Production and partial purification of cellulase by Aspergillus niger and $A$. fumigatus fermented in coir waste and sawdust. The Internet Journal of Microbiology, 3 (1): 1937-8289.

Jahangeer, S.; Khan, N.; Jahangeer, S.; Sohail, M.; Shahzad, S.; Ahmad, A.; and Khan, S.A. (2005). Screening and characterization of fungal cellulases isolated from the native environmental source. Pak. J. Bot., 37(3): 739-748.

Lowry, O.H.; Rosebrough, N.J.; Farr, A.L.; and Rondall, R.J. (1951). Protein measurement with the folin phenol reagent. J. Biol. Chem., 193: 265-275.

Miller, G.L. (1959). Use of DNS regent for the determination of reducing sugars. Anal. Chem., 31: 426428.

Okazaki, M. and Moo-Young, M. (1978). Kinetics of enzymatic hydrolysis of cellulose analytical description of a Mechanistic Model. Biotechnol. and Bioeng., 20: 637-663.

Pérez, J.; Muñoz-Dorado, J.; de la Rubia, T. and Martinez, J. (2002). Biodegradation and biological treatments of cellulose, hemicellulose, and lignin: an overview. International Microbiology, 5: 53-63.

Philippidis, G.P. (1994). Cellulase Production technology. Enzymatic Conversion of Biomass for Fuel Production. (Eds): M. E. Himmel et al., ACS symposium series 566. 
Ragab, W.S.M. (1989). Production of amylase using some microbial strains. M.Sc. Thesis, Department of Food science, Faculty of Agriculture, Assiut University, Egypt.

Rees, E.T. and Maguire, A. (1971). Increase in cellulase yield by addition of surfactants to cellobiose cultures of Trichoderma viride. Develop. Indust. Microbiol., 12: 212.

Saha, S.; Roy, R.; Sen, S.K.; and Ray, A.K. (2006). Characterization of cellulase-producing bacteria from the digestive tract of tilapia, Oreochromis mossambica (Peters) and grass carp, Ctenopharyngodon idella (Valenciennes). Aquaculture Research, 37: 380-388.

Singh, A.; Singh, N.; and Bishnoi, N.R. (2009). Production of cel- lulases by Aspergillus Heteromorphus from wheat straw under submerged fermentation. International Journal of Environmental Science and Engineering, 1: 1 .

Sohail, M.; Siddiqi, R.; Ahmad, A.; and Khan, S.A. (2009). Cellulase production from Aspergillus niger MS82: effect of temperature and $\mathrm{pH}$. New Biotechnology, 25 (6): Pages 437-441.

Takao, S.; Komagata, Y.; and Sasaki, H. (1985). Cellulose production by Penicillium purpurogenum. J. Ferment. Technol., 63: 127134.

Walsh, G. (2002). Industrial enzymes: proteases and carbohydrases. Proteins; Biochemistry and Biotechnology. John Wiley and Sons. Ltd. 
تأثير درجة حرارة التحضين على انتاج انزيمات السليوليز الفطرية

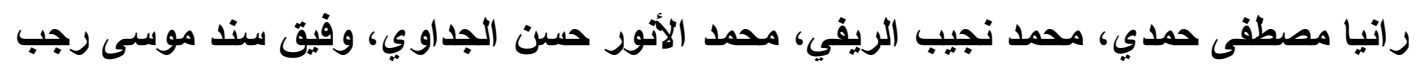

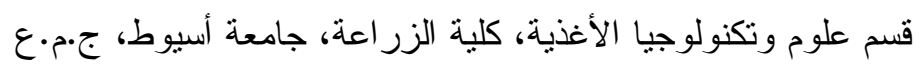

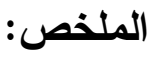

تهدف هذه الدر اسة الى اختبار وتحديد درجات حر ارة التحضين المثالية لإنتــاج انزيـــات Aspergillus flavus ،Aspergillus niger AUMC 8485 السليوليز بو اسطة فطريـات . Emericella nidulans AUMC 8581 و AUMC 8534

وقد أوضحت النتائج المتحصل عليها أن درجة الحرارة المنلى لإنتاج انزيمات الـسليوليز

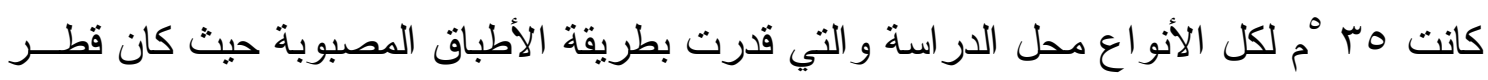

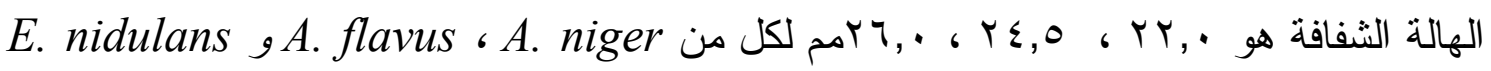

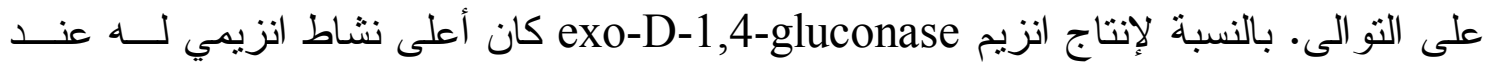

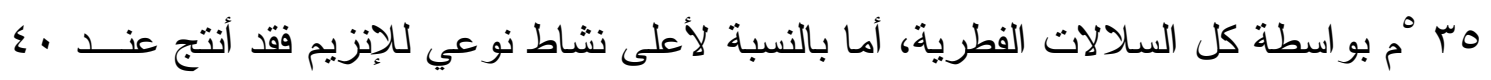

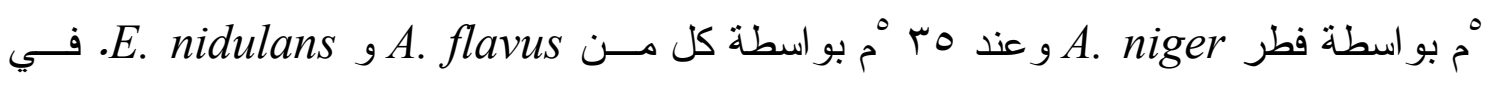

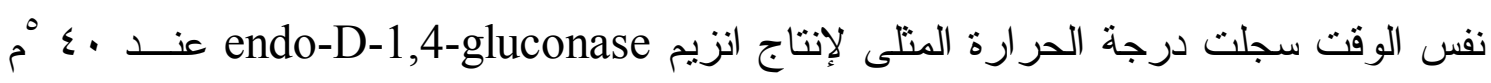

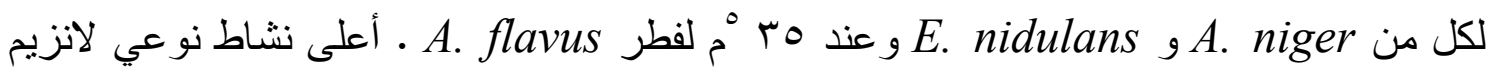
endo-D-1,4-gluconase

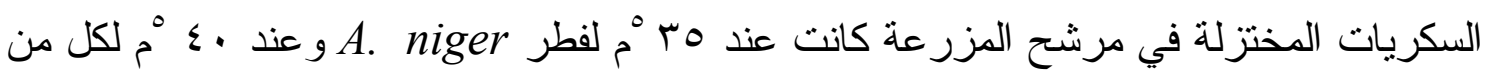
E. nidulans و. A. flavus

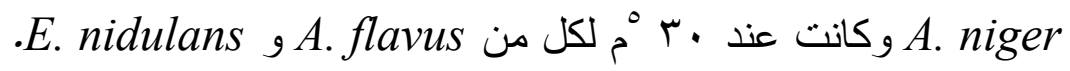

